UDC 635.64:631.52

(C) 2020

\title{
Assessment of the combined capacity of tomato source material by the sign "lycopene content in fruits»
}

\author{
Torbaniuk M. \\ Cherkasy State Agricultural Research Station of National Institute of Agriculture of NAAS \\ 13 Dokuchaieva Str., Holodnianske village, Smila region, Cherkasy oblast, 20731, Ukraine \\ e-mail: mariyatr@ukr.net \\ ORCID: 0000-0001-6748-3172
}

Goal. To assess the combinatorial ability of the tomato source material by sign «lycopene content in the fruit» in the system of diallel crosses. Methods. Field - to establish differences between variants of the experiment; laboratory - to determine the content of lycopene in the fruit; genetic - to determine the indicators of combinatorial ability; mathematical and statistical - to assess the reliability of the research results. Results. Studies identified samples that should be used for heterosis and varietal selections, as well as those that should be used only when creating synthetic varieties. The established advantages of additive effects in the genetic control of the sign «lycopene content in tomato fruits» made it possible to select phenotype in the 2nd hybrid generation. Conclusions. Samples MO 112 and T-3627 should be used to create heterosis hybrids and as a component of synthetic varieties. The Dark green sample, Alia variety, and the № 477 lines can be used to create synthetic varieties. The established advantage of additive effects in the genetic control of the sign «lycopene content in tomato fruits» makes it possible to recommend selection in the selection process by phenotype, starting from the 2 nd hybrid generation.

Key words: variety, hybrid, dialysis analysis, combination ability.

DOI: https://doi.org/10.31073/agrovisnyk202009-11

Lycopene is a unique natural antioxidant that has anti-cancer properties [1, 2]. It is considered as a biologically active component that can prevent cell damage by so-called free radicals, and is a natural method for the prevention of cardiovascular and cancer diseases [3-5]. Lycopene is found in many fruits, vegetables and berries: in particular, in the fruit of the tomato, which is the leader in its content $(0.72-20$ $\mathrm{mg} / 100 \mathrm{~g})$, guava $(5.23-5.50 \mathrm{mg} / 100 \mathrm{~g})$, grapefruit $(0.35-3.36 \mathrm{mg} / 100 \mathrm{~g})$, carrots $(0.65-0.78 \mathrm{mg} / 100 \mathrm{~g})$, apricots $(0.01-0.05 \mathrm{mg} / 100 \mathrm{~g})$, persimmons, rose hips, red cabbage and beets [6-8]. Tomato forms with mutant genes $\mathrm{hp}-2^{\mathrm{dg}}, \mathrm{B}^{\mathrm{og}}, \mathrm{B}^{\mathrm{c}}$ are high in lycopene content, but they are characterized by low productivity, late and extended ripening period, which significantly reduces their practical value [9-11]. The value of varieties and lines for use as parental forms in hybrid combinations of crosses is determined not only by their economically valuable traits, but also by their ability to give a high heterosis effect, namely, combination ability $[12,13]$. The most accurate general (GCA) and specific (SCA) combining ability is determined by diallel crosses [14, 15].

The purpose. Evaluate the combining ability of the tomato source material on the trait of "lycopene content in the fruits" in the system of diallel crosses.

Methods: field - to establish differences between the variants of the experiment; laboratory - to determine the biochemical composition of fruits, genetic - to determine the indicators of combining ability; mathematical and statistical - to assess the reliability of the research results.

Materials and methods of research. The research was conducted in 2017-2019 on the fields of breeding and seed crop rotation of Cherkasy DSGDS. As parental forms were used the line №477 (sp, u) and the Alya (sp) variety with a reduced fruit ripening period and three samples with a high lycopene content in the fruit: Dark green (hp- $\left.{ }^{\mathrm{dg}}\right)$; $M O 112(\mathrm{hp}) ; \mathrm{T}-3627\left(\mathrm{~B}^{\mathrm{c}}\right)$.

The experiments are based on the method of one-factor experiments [16]. Testing of the obtained hybrids and source material was carried out taking into account the recommendations and methodological approaches $[17,18]$. Determination of lycopene content in fruits was carried out according to the method provided by the Institute of Vegetable and Melon Growing of NAAS. Evaluation of the combining ability of the trait "lycopene content in tomato fruits" was performed according to the first scheme V.I. Griffing with a matrix of crosses and tests p2 (direct and reciprocal crosses + parent forms), where $p$ - is the quantity of parent forms according to the guidelines [19,20].

Research results. The dispersion analysis of the combining ability (table 1) shows significant differences in general and specific combining ability. In addition, in 2017 and 2018, a significant reciprocal effect was found. In this case, when there is a reciprocal effect, it can be eliminated by averaging the values of the trait in direct and inverse hybrids and take the same average values. 
1. Dispersion analysis of the combining ability of lycopene content in tomato fruits, 2017-2019

\begin{tabular}{|c|c|c|c|c|c|c|}
\hline Year & Source & $\begin{array}{l}\text { Sum of } \\
\text { Squares }\end{array}$ & $\begin{array}{l}\text { Degrees of } \\
\text { freedom }\end{array}$ & $\begin{array}{c}\text { Mean } \\
\text { Squares }\end{array}$ & F estim. & F tabl. \\
\hline \multirow{5}{*}{$\stackrel{\hat{\sigma}}{\circ}$} & Hybrids & 371,6 & 24 & $15,5^{*}$ & 225,6 & 1,79 \\
\hline & GCA & 29,2 & 4 & $7,3^{*}$ & 319,1 & 2,61 \\
\hline & SCA & 66,7 & 10 & $6,7^{*}$ & 291,4 & 2,08 \\
\hline & $\begin{array}{l}\text { Reciprocal } \\
\text { effects }\end{array}$ & 28,0 & 10 & $2,8^{*}$ & 122,5 & 2,08 \\
\hline & Error & 1,1 & 48 & $0,02^{*}$ & & \\
\hline \multirow{5}{*}{$\stackrel{\infty}{\infty}$} & Hybrids & 268,1 & 24 & $11,2^{*}$ & 9,7 & 1,79 \\
\hline & GCA & 47,7 & 4 & $11,9^{*}$ & 31,1 & 2,61 \\
\hline & SCA & 20,2 & 10 & $2,0^{*}$ & 5,3 & 2,08 \\
\hline & $\begin{array}{l}\text { Reciprocal } \\
\text { effects }\end{array}$ & 21,5 & 10 & $2,2^{*}$ & 5,6 & 2,08 \\
\hline & Error & 18,4 & 48 & $0,4^{*}$ & & \\
\hline \multirow{5}{*}{$\frac{\pi}{2}$} & Hybrids & 160,8 & 24 & $6,7^{*}$ & 9,4 & 1,79 \\
\hline & GCA & 47,1 & 4 & $11,8^{*}$ & 49,5 & 2,61 \\
\hline & SCA & 4,5 & 10 & 0,4 & 1,9 & 2,08 \\
\hline & $\begin{array}{c}\text { Reciprocal } \\
\text { effects }\end{array}$ & 2,0 & 10 & 0,2 & 0,9 & 2,08 \\
\hline & Error & 11,4 & 48 & 0,2 & & \\
\hline
\end{tabular}

Note. ${ }^{*}$ significant at 0.95 level.

We found that samples MO 112 and T-3627 for three years had a high (reliable positive effects) GCA - 0.25-1.21 and 0.49-0.96, respectively, the sample Dark green high value GCA (1.02) had only in 2017 , in other years of research - the average values of the effects of GCA (Table 2).

2. Effects of the general combining ability (GCA) of the trait of "lycopene content in tomato fruits", mg / 100 g, 2017-2019

\begin{tabular}{|c|c|c|c|}
\hline Variety, line & 2017 & 2018 & 2019 \\
\hline Line №477 & $-0,88^{*}$ & $-0,92^{*}$ & $-1,24^{*}$ \\
\hline Alya & $-0,89^{*}$ & $-1,26^{*}$ & $-1,01^{*}$ \\
\hline Dark green & $1,02^{*}$ & 0,05 & 0,23 \\
\hline MO 112 & $0,25^{*}$ & $1,18^{*}$ & $1,21^{*}$ \\
\hline T-3627 & $0,49^{*}$ & $0,96^{*}$ & $0,80^{*}$ \\
\hline $\mathrm{P}_{05}$ & 0,09 & 0,35 & 0,28 \\
\hline
\end{tabular}

Note. * significant at 0.95 level.

Variety Alya and line №477 had a low (significant negative estimates of effects) assessment of GCA - from minus 0.89 to minus 1.26 and from minus 0.88 to minus 1.24 , respectively.

Significant differences in specific combining ability (SCA) indicate that some hybrid combinations within the variety differed significantly from its average value. Thus, based on the fact that general combining ability (GCA) is equivalent to additivity, and spesific combining ability (SCA) is equivalent to non-allelic interaction of genes, in the system of genetic control the main part in the set of varieties is represented by genes with additive effects. At the same time, significant contribution and non-additive effects were revealed. In order to identify lines and varieties with high or low SCA, for each parental form, variance was calculated for comparison with the total average value (Table 3 ). 
3. Evaluation of variance of effects of general combining ability (GCA) and spesific combining ability (SCA) for evaluation of lines and varieties on the trait of lycopene content in tomato fruits, $m g / 100 g, 2017-2019$

\begin{tabular}{|c|c|c|c|c|c|c|c|}
\hline Variety, line & Year & Alya & $\begin{array}{c}\text { Dark } \\
\text { green }\end{array}$ & $\mathrm{MO}-112$ & T-3627 & $\delta_{S i}{ }^{2}$ & $\delta_{g_{1}}{ }^{2}$ \\
\hline \multirow{3}{*}{$\begin{array}{l}\text { Line № } \\
477\end{array}$} & 2017 & $0,46^{*}$ & $-1,05^{*}$ & $-0,68^{*}$ & $-0,59^{*}$ & 0,52 & 0,77 \\
\hline & 2018 & $-0,45$ & $-0,04$ & 0,07 & 0,24 & $-0,22$ & 0,79 \\
\hline & 2019 & 0,38 & $-0,07$ & $-0,18$ & $-0,77^{*}$ & $0,01^{*}$ & 1,50 \\
\hline \multirow[t]{3}{*}{ Alya } & 2017 & & $-1,44^{*}$ & $-0,45^{*}$ & $2,96^{*}$ & $2,79^{*}$ & 0,79 \\
\hline & 2018 & & $0,96^{*}$ & $-0,25$ & $-0,64$ & 0,11 & 1,53 \\
\hline & 2019 & & $-0,48$ & $-0,31$ & 0,44 & $-0,01$ & 0,98 \\
\hline \multirow[t]{3}{*}{ Dark green } & 2017 & & & $1,14^{*}$ & $-1,57^{*}$ & 1,72 & 1,03 \\
\hline & 2018 & & & $-1,35^{*}$ & 0,15 & 0,41 & $-0,05$ \\
\hline & 2019 & & & 0,16 & $-0,41$ & $-0,07$ & 0,02 \\
\hline \multirow[t]{3}{*}{ MO 112} & 2017 & & & & $-2,32^{*}$ & 1,81 & 0,06 \\
\hline & 2018 & & & & $2,12^{*}$ & $1,32^{*}$ & 1,34 \\
\hline & 2019 & & & & 0,13 & $-0,14$ & 1,43 \\
\hline \multirow[t]{3}{*}{ T-3627 } & 2017 & & & & & $4,22^{*}$ & 0,23 \\
\hline & 2018 & & & & & $0,96^{*}$ & 0,87 \\
\hline & 2019 & & & & & $0,06^{*}$ & 0,60 \\
\hline \multirow{3}{*}{$\begin{array}{c}\text { Average } \\
\text { value }\end{array}$} & 2017 & & & & & 2,21 & \\
\hline & 2018 & & & & & 0,52 & \\
\hline & 2019 & & & & & $-0,03$ & \\
\hline
\end{tabular}

Note. $\delta_{S i}{ }^{2}$ - variance of the effect of specific combining ability; $\delta_{g_{1}}{ }^{2}$ - variance of the effect of general combining ability.

Comparing the variants of SCA with their diallel average value, we found that over the years of research, a high annual value of SCA was observed in the sample T-3627 (0.06-4.32). Sample MO 112 (carrier of the hp gene), line №477 and variety Alya changed the value of SCA under the influence of external factors (from high to low).

Comparison of the variance of the effects of general $\left(\delta_{g_{1}}{ }^{2}\right)$ and specific $\left(\delta_{S i}{ }^{2}\right)$ combining ability revealed that in the line №477 (for three years of research), Alya variety (with normal lycopene content in fruits), sample MO 112 (with high lycopene content) for two years of research $\delta_{g_{1}}{ }^{2}>\delta_{S i}{ }^{2}$, which indicates the predominance of additive effects of genes in the genetic control of the trait "lycopene content in fruits". The advantage of additive effects in determining the value of the trait allows to recommend selection in the breeding process by phenotype. In samples of Dark green and T-3627 for two years of research $\delta_{g_{1}}{ }^{2}<\delta_{S i}{ }^{2}$, which indicates the advantage of non-additive effects. 


\section{Conclusions}

After analyzing the results of the study of combining ability, it should be noted that the samples MO 112 and T-3627 can be used both to create heterosis hybrids and as a component of synthetic varieties. Sample Dark green (with high and medium values of GCA effects and medium values of SCA), Alya variety and line №477, which have low values of GCA effects and cannot be used in heterosis breeding for high lycopene content in fruits, can be used to create synthetic varieties.

The established advantage of additive effects in the genetic control of the trait "lycopene content in tomato fruits" allows to recommend selection in the breeding process by phenotype, starting from the second hybrid generation.

\section{References}

1. Timofeev, N.N., Volkova, N.N., \& Chizhov, S.T. (I.A. Prokhorov (Ed.)). (1972). Selektsiya i semenovodstvo ovoshchnykh kultur [Breeding and seed production of vegetable crops]. Ed. 2nd, reworked. and add. Moscow: Kolos [in Russian].

2. Sharma, P., Thakur, S. \& Negi, R. (2019). Recent Advances in Breeding of Tomato. A Review. International Journal of Current Microbiology and Applied Sciences. 8. (3).1275-1283.

3. Li, X., Xu, J. (2014). Meta-analysis of the association between dietary lycopene intake and ovarian cancer risk in postmenopausal women. Sci. Rep., 4. 4885. doi: 10.1038/srep04885

4. Pouchieu, C., Galan, P., Ducros, V., Latino-Martel, P., Hercberg, S., \& Touvier, M. (2014). Plasma carotenoids and retinol and overall and breast cancer risk: a nested case-control study. Nutr. Cancer, 66, 980-988. doi: 10.1080/01635581.2014.936952

5. Tang, L., Lee, A.H., Su, D., \& Binns, C.W. (2014). Fruit and vegetable consumption associated with reduced risk of epithelial ovarian cancer in southern Chinesewomen. Gynecol. Oncol., 132, 241-247. doi: 10.1016/j.ygyno.2013.10.0209

6. Avdeev, A. Yu. (2012). Selektsiya tomata dlya raznykh tseley ispolzovaniya, klassifikatsiya sortov i tekhnologii vyrashchivaniya $\vee$ Nizhnem Povolzhe [Breeding of tomato for different purposes, classification of varieties and cultivation technologies in the Lower Volga region]. Astrakhan [in Russian].

7. Preedy, V.R., \& Watson, R.R. (2008). Tomatoes and Tomato Products: Nutritional, Medicinal and Therapeutic Properties. Enfield: Science Pudlishers.

8. Di Gioia, F., Tzortzakis, N., Rouphael, Y., Kyriacou, M.C., Sampaio, S.L., Ferreira, I.C., \& Petropoulos, S.A. (2020). Grown to be Blue-Antioxidant Properties and Health Effects of Colored Vegetables. Part II: Leafy, Fruit, and Other Vegetables. Antioxidants, 9. 41. doi: 10.3390/antiox8120617

9. Mochizuki, T. (1995). Studies on lines with high pigment genes as high vitamin $C$ and carotenoid sources in tomato breeding. Bull. Veg. Orgaam. Grops Res. Stn. Ser. A., 10, 55-139.

10. Gurin, M.V. (2010). Dzherela biokhimichnykh oznak plodu v selektsii [Sources of biochemical characteristics of the fetus in breeding]. Bulletin of the Central Executive Committee of the APV of the Kharkiv region, 8, 39-50. [in Ukraine].

11. Samovol, O.P., \& Kondratenko, S.I. (O.P. Samovola, O.M. Mohylnoi (Eds.)). (2018). Tomat (henetychni osnovy selektsii) [Tomato (genetic basis of breeding)]. Monograph. Vinnytsia: Nilan Ltd. [in Ukraine].

12. Turbin, N.V., \& Khotyleva, L.V. (1961). O printsipakh i metodakh selektsii rasteniy na kombinatsionnuyu sposobnost [On the principles and methods of plant breeding for combining ability]. Heterosis. Minsk [in Russian].

13. Kumar, P.A., Reddy, R. K., Reddy, R.V.S.K., Pandravada S.R. \& Saidaiah P. (2019). Heterosis in dual purpose tomato for yield and quality attributes under Southern Telangana region. International Journal of Chemical Studies, 7 (3), 494-503.

14. Hayman, B.I. (1954). The theory and analysis of diallel crosses. Genetics, 39 (6), 789-809.

15. Jinks, I.L. (1954). The analysis of continuous variation in a diallel cross of Nicotiana rustica varieteis. Genetics, 39 (6), 767-788.

16. Dospekhov, B.A. (1985). Metodika polevogo opyta [Methods of field experience] [Uch. Manual]. Moscow: Agropromizdat [in Russian].

17. Bondarenko, G.L., Yakovenko K.I. (Eds.)). (2001). Metodyka doslidnoi spravy $v$ ovochivnytstvi $i$ bashtannytstvi [Methods of research in vegetable and melon growing]. Kharkiv [in Ukraine].

18. Horovoi, T.K. (Eds.)). (2001). Suchasni metody selektsii ovochevykh i bashtannykh kultur [Modern methods of breeding of vegetable and melon crops]. Kharkiv [in Ukraine].

19. Griffing, B.I. (1956). A generalized treatment of the use of diallel crosses in quantitative inheritance. Heredity, 10 (1), 31-50.

20. Volf, V.G., \& Litun, P.P. (1980). Metodicheskie rekomendatsii po primeneniyu matematicheskikh metodov dlya analiza eksperimentalnykh dannykh po izucheniyu kombinatsionnoy sposobnosti [Methodical recommendations for the application of mathematical methods for the analysis of experimental data on the study of combinsng ability]. Kharkiv [in Russian]. 